\title{
1.T. INVESTMENT AND INTANGIBLES:
} EVIDENCE FROM BANKS

Alfredo Martin-oliver and Vicentes Salas - tumás

Documentos de Trabajo N. 1020

\section{BAN TO EE ESPANAa}

\author{
Eurosistema
}


I.T. INVESTMENT AND INTANGIBLES: EVIDENCE FROM BANKS 
I.T. INVESTMENT AND INTANGIBLES: EVIDENCE FROM BANKS ${ }^{(*)}$

\author{
Alfredo Martín-Oliver ${ }^{(*)}$ \\ BANCO DE ESPAÑA \\ Vicente Salas-Fumás \\ UNIVERSIDAD DE ZARAGOZA
}

(*) This paper is the sole responsibility of its authors and the views represented here do not necessarily reflect those of the Banco de España. Any errors are entirely the authors' own responsibility. We thank three anonymous referees for their comments to a previous version of the paper. V. Salas-Fumás acknowledges the financial support from project SEJ 2007-67895-C04-04.

(*) Address for correspondence: Alfredo Martín-Oliver; c/Alcalá, 48, 28014 Madrid, Spain. Tlf: + 3491338 6178; Fax: + 3491338 6102; e-mail: alfredo.martin@bde.es. 
The Working Paper Series seeks to disseminate original research in economics and finance. All papers have been anonymously refereed. By publishing these papers, the Banco de España aims to contribute to economic analysis and, in particular, to knowledge of the Spanish economy and its international environment.

The opinions and analyses in the Working Paper Series are the responsibility of the authors and, therefore, do not necessarily coincide with those of the Banco de España or the Eurosystem.

The Banco de España disseminates its main reports and most of its publications via the INTERNET at the following website: http://www.bde.es.

Reproduction for educational and non-commercial purposes is permitted provided that the source is acknowledged.

\section{(C) BANCO DE ESPAÑA, Madrid, 2010}

ISSN: 0213-2710 (print)

ISSN: 1579-8666 (on line)

Depósito legal: M. 30124-2010

Unidad de Publicaciones, Banco de España 


\section{Abstract}

This paper models the investment behaviour of a multi-asset firm with market power that accumulates valuable intangible assets to complement the IT capital. The investment model is estimated using data from Spanish banks on assets of different nature: material (branches, financial), immaterial (advertising and IT) and intangible (training of workers). The paper estimates that the representative bank spends five additional Euros per Euro invested in IT-related assets in complementary intangible assets or, equivalently, intangibles amount to approximately $10 \%$ of the economic value of the representative bank. The remaining economic value is distributed between $28 \%$ from rents attributed to market power, and $62 \%$ to the cost of market-purchased assets.

Keywords: multi-asset firm; investment; intangible assets; banks.

JEL: G21; D92 


\section{Introduction}

Intangible assets have received increasing recognition as sources of the economic value of individual firms [Lev (2001); Brynjolfsson, Hitt and Yang (2002); Hulten and Hao (2008)] and as sources of countries' economic growth [Buiges, Jacquemin, Marchipont (2000); Corrado, Haltiwanger, Sichel (2005); Corrado, Hulten and Sichel (2009); Marrano, Haskel and Wallis (2009), Fukao et al. (2009)]. Assets identified as intangibles are not homogenous, and their measurement raises controversies. Most often, intangibles refer to immaterial assets, such as those resulting from R\&D, advertising and information technology (IT) expenditures. However, intangible assets are also defined, in a more restrictive way, as the assets that firms build up internally as a sub-product of their regular activities, such as production of goods and/or investment in market-purchased assets. Examples of the latter are the "organizational capital" of Prescott and Visscher (1980) and the "organization capital" of Brynjolfsson, Hitt and Yang (2002) and Lev and Radhakrishnan (2005). ${ }^{1}$ Both immaterial and intangible assets are most often registered as expenses of the year by conventional accounting practices, even though these expenditures increase future consumption opportunities and they could be justified being accounted as investments [Blair and Wallman (2001); Corrado, Hulten and Sichel (2009); Corrado, Haltiwanger and Sichel (2005)].

Different approaches have aimed to obtain a measure of the unreported intangible assets of firms, though they present several caveats. The approach of measuring the amount of intangible assets as the difference between market and book value of the firm [Hall (2001) and Villalonga (2004)] does not separate the cost of investment in the assets and the economic value that those assets contribute to create (economic rents). ${ }^{2}$ The use of expenditures reported in separate lines of the income statement to obtain estimates of the stock of intangibles [a practice going back to Griliches (1981)], common in macro-economic analysis [Corrado, Hulten and Sichel (2009); Marrano, Haskel and Wallis (2009), Fukao et al. (2009)], abstracts from the ex-ante investment decision process of the firms, and does not make an explicit distinction between market-purchased assets and assets resulting from production and/or investment activities, such as organization capital. Oliner, Sichel and Stiroh (2007) use the model proposed by Basu, Oulton and Srinivasan (2003) to obtain estimates of intangible capital related to IT. In this model, the IT capital and the intangibles are complementary assets that are combined to generate flows services used as inputs of the production function of the firm. Assuming that firms choose the mix of IT and intangibles in an efficient way, the growth of the (invisible) stock of intangibles can be estimated as a function of the growth of the (observable) IT capital. Nonetheless, the model does not explicitly link intangibles with the outcome of adjustment costs, nor does it consider the possibility of market power of banks. Finally, hedonic-price approaches to measuring the value of intangible assets [Cockburn and Griliches (1988), Hall (1993)] estimate the marginal contribution of each asset to the value of the firm, tangible and intangible, but do not separate the estimated marginal contribution in purchase costs, adjustment costs (that may turn into organization capital) and contribution in the form of rents, from market power.

1. Lev and Radhakrishnan (2005) and Cummins (2004) say that the word intangibles should be used only to refer to built-in intangibles, such as organization capital. In this paper, we make a distinction between immaterial (advertising, and IT purchased in the market) and intangibles.

2. Another problem is that the market price of the shares of firms may be affected by bubbles, and other possible inefficiencies, causing a deviation between the market and the fundamental value of the firm. 
This paper proposes an ex-ante decision model of the investment behaviour of a multiasset firm that provides a comprehensive approach to the valuation of the firm and of all its invested assets. The results of the model are empirically applied to data from Spanish banks for the period 1984-2003, to obtain estimates of the value of the stock of intangible assets built in the process of investing in IT capital. Recent research on the so-called "IT revolution" and "new economy" has called attention to how advances in IT opened the way to new work processes, new job definitions and new management functions in firms of all economic sectors. The new business models lowered the costs of the old activities and allowed firms to implement new ones [Brynjolfsson, Hitt and Yang (2002)]. In this paper, we have grouped all these capabilities, resulting from investment and use of IT-related assets, under the "organizational capital" of the firm. Therefore, our approach to the measurement of intangibles makes an explicit distinction between market-purchased immaterial assets (advertising and IT capital) and intangibles that are internally generated as a sub-product during the process of making IT capital fully productive. With the data available for each bank on expenditures in training workers, we obtain estimates of the part of the adjustment costs that become intangible assets. These intangible assets are a part of the human capital that enables workers to use computers more efficiently [Bresnahan, Brynjolfsson and Hitt (2002)]. Finally, we split the value of intangibles into their cost of accumulation, and the value of the rents from market-power that these intangibles may generate.

The theoretical model is drawn from the theory of investment of a multi-asset firm that maximizes its economic value subject to adjustment costs of growth WWildasin (1984); Hayashi and Inoue (1991); Brynjolfsson and Yang (1999); Bond and Cummins (2000)]. We extend the basic model in two ways: i) firms have market power; and ii) the intangible assets that firms build in the process of making IT capital productive (organizational capital) contribute positively to the profits of the firm. ${ }^{3}$ Bond and Cummins (2000) modelled and estimated the investment equation for the multi-asset firm, but assumed perfect competition and do not explicitly relate adjustment cost from IT assets accumulation with the outcome in the form of organizational capital. Brynjolfsson and Yang (1999) and Cummins (2004) link the adjustment costs from IT investment with built-in intangibles, but they model the valuation equation of the firm (not the investment equation, as we do in this paper), they assume perfect competition, and they do not make explicit the contribution of the built-in intangibles to profits.

In the empirical application, the paper uses estimates of the stock of several market-purchased assets valued at replacement cost: material assets (branches and equipment), immaterial assets (advertising and IT capital), financial assets, and human capital (from training). The theory predicts that, if the adjustment costs (such as the costs of training workers to use computers) turn into valuable intangible assets, then the estimated adjustment cost of investing in IT capital will be decreasing with the marginal economic value of these intangibles. The other prediction (related to the extensions of the investment model) states that banks with market power will invest at a lower rate than banks with no market power. The empirical estimations of the investment equation for the multi-asset bank do a good job in explaining the valuemaximizing investment behaviour of Spanish banks. The empirical results confirm that human capital from training workers is an intangible asset built in the process of investing in IT that contributes to the economic value of the bank. Finally, the results also confirm that banks have market power, especially in the deposits market. The assets that seem to contribute to market

3. Market power can be interpreted as a hidden cost of growth, since it implies that as firms expand capacity they will lower future revenues of output from current capacity, since they will have to lower the price as a way to increase demand. This cost has been considered in single-asset investment models based on Euler's equations [Schiantarelly and Georgoutsos (1990), Bond and Meghir (1994)]. 
power are advertising capital and (marginally) intangibles (no evidence is found of a contribution for IT, physical or financial assets). ${ }^{4}$

To our knowledge, this is the first application of the multi-asset Tobin's q investment model to banks, and also the first to study in depth the process of IT investment and intangibles in the banking industry. The distinct feature of the banking firm in the model is that the investment in financial assets, which is one of the explanatory variables of the investment equation, can be used to infer possible restraints on the banks in satisfying their requirements of regulatory capital. The empirical analysis finds no evidence of such restraints, probably because the time period considered in this study has been relatively favourable in terms of macroeconomic conditions, and banks have been able to meet their solvency requirements without major difficulty.

The rest of the paper is organized as follows. In Section 2, we present the derivation and interpretation of the investment function for the multi-asset bank. In Section 3, we present the description of the database, the results of the empirical estimation of the investment equation using data from Spanish banks, and a discussion of the results. The conclusion summarizes the main results of the paper.

\footnotetext{
4. Besides the debate on whether IT investment turns into intangible assets or not [see for example the different views on this issue by Brynjolfsson, Hitt and Yang (2002) and Cummins (2004), there is another debate on whether IT-related assets give a competitive advantage to firms, so that investment in IT turns into economic rents [Bharadwaj, Bharadwaj and Konsynski (1999)] or not [Carr 2003)]. See Beccalli (2007) for an empirical analysis of the relationship between IT investment and the profitability of banks, using accounting data.
} 


\section{The investment model}

\subsection{Hypotheses}

We consider a bank that issues equity to finance the assets needed to produce and deliver banking services, and also to satisfy the minimum regulatory equity requirements. The economically optimal volume of equity on the liability side of the balance sheet of the bank will then be equal to the sum of the stocks of physical assets, IT-related assets, advertising capital (operating assets of the bank), and the stock of financial assets, all on the asset side of the balance sheet. We do not model the choice of the capital ratio of the bank, but consider that banks' equity always satisfies the minimum capital requirements set by regulation. From these assumptions, we can focus on the optimal decisions concerning resources that are the counterpart to the equity on the asset side of the balance sheet, including the financial assets. In this section, we formulate the model that determines the investment equation for a general firm with $N$ different assets, assuming that the firm has market power, and that there is one asset for which adjustment costs turn into valuable intangible assets (organizational capital).

In each time period, the firm/bank decides how much to invest in each type of $N$ different market-purchased capital goods, $\boldsymbol{I}_{t}=\left(I_{1 t}, I_{2 t}, \ldots, I_{N_{t}}\right)$. The firm holds a stock of capital services at the beginning of the period $t, \boldsymbol{K}_{t-1}=\left(K_{1 t-1}, \ldots, K_{N t-1}\right)$ that changes over time as the result of new investments and of the depreciation of old ones,

$$
K_{j, t+s}=\left(1-\delta_{j}\right) K_{j, t+s-1}+I_{j, t+s} \quad \text { for } \mathrm{j}=1, \ldots ., \mathrm{M} \text { and } \quad s>0
$$

where $\delta$ is the depreciation rate of capital asset $j$.

To make fully productive the new invested assets, the firm has to incur adjustment costs. Let $C($.$) be the adjustment cost function that is assumed separable in the adjustment costs of$ each of the assets in which the firm invests,

$$
C\left(K_{s}, I_{s}\right)=\sum_{j} C_{j}\left(K_{j}, I_{j}\right)=\sum_{j} p_{j} \frac{b_{j}}{2}\left(\frac{I_{j}}{K_{j}}-a_{j}\right)^{2} K_{j}
$$

where $b_{j}$ is a positive (cost) parameter and $a_{j}$ is the stationary investment rate for which adjustment costs are zero (in general equal to the depreciation rate), and $p_{j}$ is the market purchase price of one unit of asset $j$. The adjustment cost function is defined in Euros of new investments that do not turn into capital stock of the respective productive asset. ${ }^{5}$

The new assumption introduced in the paper is that the adjustment costs incurred in certain investments are accumulated into a valuable intangible asset (valuable because it positively affects the cash flow of the firm). In the paper, sub-index $k$ identifies the assets whose investments imply building complementary intangible assets. In the empirical analysis, $k$ will be limited to IT capital and the associated intangibles are, among others, those accumulated in the form of human capital from training workers in the use of computers, and related assets. Let $M_{k}$ be the stock of intangible assets resulting from expenditures in the form of

5. Although it would be realistic to assume a non-separable adjustment cost function, for simplicity, we maintain the assumption of separable adjustment cost functions. 
adjustment costs associated with the market- purchased asset $k$. The stock $M_{k}$ will vary over time as the net result of depreciation and the flow of new intangibles from current expenses in adjustment costs, $C_{k}$ :

$$
M_{k t}=\left(1-x_{k}\right) \cdot M_{k, t-1}+f\left(C_{k t}\right)
$$

where $x_{k}$ is the depreciation rate of the intangible assets and $f\left(C_{k t}\right)$ is the flow of intangibles produced with the adjustment costs incurred in period $t$, which in turn depends on $I_{k}$ and $K_{k}$ [from equation (2)] We assume that $f\left(\right.$ ) increases with the expenditures in adjustment costs, $C_{k}$.

Let $\Pi\left(\boldsymbol{K}_{s}, M_{\mathrm{ks}}, \boldsymbol{I}_{s}, e_{s}\right)$ be the net cash flow of the firm in period $s$ as a function of the stock $K_{s}$ and the investment flow $I_{s}$ of the assets in the period, and of the random productivity shock $e_{s}$, once the non-capital inputs used in the production, for example labour, are optimized. The stock of intangible asset $M$ enters the cash flow function because it is assumed to be a valuable asset. The cash flow function has three separate components: gross revenues from operations, adjustment costs, and the outlay from current market-purchased assets:

$$
\Pi\left(K_{s}, M_{k s}, I_{s}, e_{s}\right)=R\left(K_{s}, M_{k s}, e_{s}\right)-C\left(K_{s}, I_{s}\right)-\sum_{j} p_{j s} I_{j s}
$$

Gross revenue $R($.$) is in turn equal to the price times the quantity of product sold, R()=$. $\left(Q\left(K_{s}, M_{k s}\right)\right) Q\left(K_{s}, M_{k s}\right)$, where price is non-increasing with the quantity sold (i.e. firms can have market power); $p_{j s}$ is the current market purchase price of one unit of capital asset $j$, and $C($.$) is$ given by (2).

The economic value of the firm in period $t, V_{t}$, will be equal to the present value of expected future cash flows,

$$
V_{t}=E_{t}\left\{\sum_{s=t}^{\infty} \beta_{s}^{t} \cdot \Pi\left(K_{s}, M_{k s}, I_{s}, e_{s}\right)\right\}
$$

where $E_{t}$ is the expectations operator, conditional on the information available at the beginning of period $t$, and $\beta_{s}^{t}$ is the discount factor.

The optimization problem of the firm is to choose $I, K$ and $M$ such that (4) is maximized subject to (1), (2) and (3). The detailed solution to this problem is presented in Appendix A. Here, we focus on the two equations that result from the optimization:

$$
\begin{gathered}
V_{t}=\sum_{j} \lambda_{j t}\left(K_{j t}-I_{j t}\right)+z_{k t} M_{k t}+\sum_{s=t}^{\infty} \beta_{s}^{t} \frac{1}{\varepsilon} p\left(Q\left(K_{s}\right)\right) \cdot Q\left(K_{s}\right) \\
\lambda_{j t}=p_{j t}+C_{I j t}^{\prime} \quad \text { if } j \neq k \\
\lambda_{k t}=p_{k t}+C_{I k t}^{\prime}-z_{k t} f_{C_{k}}^{\prime} C_{I k t}^{\prime} \quad \text { if } j=k
\end{gathered}
$$

where $\lambda_{j t}$ and $z_{k t}$ are the Lagrange multipliers for constraints (2) and (3), respectively, and $C_{\text {Ijt }}^{\prime}$ is the marginal adjustment cost for the investment flow in asset $j$ [derivative with respect to investment flow of the adjustment cost function (2)]. 


\subsection{Discussion of the model}

Substituting $C_{l j}^{\prime}$ from (2) in (5.2), and re-arranging the terms, we obtain the optimal investment path for asset $j$ as a function of the marginal $q$ ratio $\lambda_{j t} / p_{j t}=q_{j t}$.

$$
\begin{gathered}
\frac{I_{j t}}{K_{j t}}=a_{j}+\frac{1}{b_{j}}\left(q_{j t}-1\right) \quad \text { if } j \neq k \\
\frac{I_{k t}}{K_{k t}}=a_{k}+\frac{1}{b_{k}\left(1-z_{k t} f_{C_{k t}}^{\prime}\right)}\left(q_{k t}-1\right) \text { if } j=k
\end{gathered}
$$

The first investment equation is a formulation of the " $q$ theory of investment" [Hayashi (1982)]; the second is modified to capture the assumption that adjustment costs generate valuable intangible assets $\left(z_{k}>0\right)$. According to (6), when $z_{k}>0$ then the effective parameter of the adjustment cost for market-purchased asset $k$ is reduced to $b_{k}\left(1-z_{k t} f_{C_{k t}}^{\prime}\right)$. This parameter is lower than in the case where intangible assets are not valuable $\left(z_{k}=0\right)$. Therefore, the theory predicts that the same $q$ ratio will imply higher investment rate when the adjustment costs generate valuable intangible assets, than when no intangibles are produced.

In the case of only one asset, under certain regularity conditions (linear homogeneous functions), the unobservable marginal $q$ can be replaced by the average $q$ [Hayashi (1982)]. For the multiple-asset firm, a separate $q$ investment function for each asset cannot be specified, since there is no average $q$ that provides a proxy for the marginal $q$ for each individual asset. However, we can obtain the investment equation of the multi-asset firm substituting (6) in (5.1) and making use of the approximation $\frac{\lambda_{j}}{p_{j}} \cong b_{j} \frac{\left(1-\delta_{j}\right) I_{j}}{K_{j t-1}}$. This approximation comes from the result that the investment rate is an increasing function of the marginal $q$. Rearranging terms after the substitution, we obtain: ${ }^{6}$

$$
\begin{aligned}
& \frac{I_{1 t}}{K_{1 t-1}}=a_{1}+\frac{1}{b_{1}\left(1-\delta_{1}\right)}\left(\frac{V_{t}}{p_{1 t} K_{1 t-1}}-1\right)-\sum_{j \neq 1} \frac{b_{j}}{b_{1}} \frac{\left(1-\delta_{j}\right) p_{j t} I_{j t}}{\left(1-\delta_{1}\right) p_{1 t} K_{1 t-1}} \\
& -\frac{b_{k}}{b_{1}} \frac{\left(1-\delta_{k}\right)\left(1-z_{k t} f_{C_{k t}^{\prime}}^{\prime}\right) p_{k t} I_{k t}}{\left(1-\delta_{1}\right) p_{1 t} K_{1 t}}-\frac{z_{k t} M_{k t}}{b_{1}\left(1-\delta_{1}\right) p_{1 t} K_{1 t}}- \\
& \frac{1}{b_{1}\left(1-\delta_{1}\right) p_{1 t} K_{1 t-1}}\left(\sum_{s=t}^{\infty} \beta_{s}^{t} \frac{1}{\varepsilon} p\left(Q\left(K_{s}\right)\right) \cdot Q\left(K_{s}\right)\right)+e_{t}
\end{aligned}
$$

Equation (7) is an extension of the investment function derived by Bond and Cummins (2000), to situations where: (i) firms have market power, and (ii) firms have adjustment costs from IT investments that become valuable intangible assets. Suppose that asset 1 is the material asset and the other assets are immaterial. The first term on the right-hand side of (7) is the marginal return of material assets when this return is estimated with the partial average $q$,

6. Bond and Cummins (2000) derive their investment equation assuming a given proportion between tangible and intangible stocks of capital assets. Under this assumption, their investment equation is the same as that derived in our paper. 
that we call $q^{P h}\left(q^{P h}=\frac{V_{t}}{p_{1} K_{1 t-1}}\right)$. If the firm deploys only material assets and operates in a perfectly competitive market, the remaining terms on the right-hand side of (7) will be equal to zero, and the optimal investment rate would only depend on the partial average $q$ ratio (as in the most conventional investment models).

Our investment equation (7) considers material assets $(j=1)$ and immaterial assets $(j>1)$. The term $-\sum_{j \neq k} \frac{b_{j}}{b_{1}} \frac{\left(1-\delta_{j}\right) p_{j t} I_{j t}}{\left(1-\delta_{1}\right) p_{1 t} K_{1 t-1}}-\frac{b_{k}}{b_{1}} \frac{\left(1-\delta_{k}\right) p_{k t} I_{k t}}{\left(1-\delta_{1}\right) p_{1 t} K_{1 t-1}}$ can be interpreted as the correction for the over-estimation of the marginal return of the material asset, when such return is estimated excluding other productive immaterial assets used by firms. The two terms of opposite sign $\frac{b_{k}}{b_{1}} \frac{\left(1-\delta_{k}\right) z_{k t} f_{C_{k t}}^{\prime} p_{k t} I_{k t}}{\left(1-\delta_{1}\right) p_{1 t} K_{1 t}}-\frac{z_{k t} M_{k t}}{b_{1}\left(1-\delta_{1}\right) p_{1 t} K_{1 t}}$ appear together in (7) when the adjustment costs become valuable intangible assets ( $z_{k t}$ is positive). The value of the difference gives the net correction in the estimate of the marginal return from investment in physical capital when the firm accumulates valuable intangible assets: the positive term gives the contribution to value from the adjustment costs accompanying investment in IT, and the negative term gives the replacement cost of the stock of intangible assets (from the condition that marginal value $z$ is equal to marginal cost), both per unit of stock of physical capital.

$$
\text { Finally, }-\frac{1}{b_{1} p_{1}\left(1-\delta_{1}\right) K_{1 t-1}}\left(\sum_{s=t}^{\infty} \beta_{s}^{t} \frac{1}{\varepsilon} p\left(Q\left(K_{s}\right)\right) \cdot Q\left(K_{s}\right)\right) \text {, is the effect of market power in the }
$$
investment behaviour of the bank. The effect is negative, since the increase in capacity derived from the new investment will imply a reduction in the price to sell the additional production. In the period-by-period profit-maximizing solution, the firm with market power sets the relative difference of price $p$ and marginal cost $m c$ equal to the inverse of the price elasticity of demand $\left(\frac{p-m c}{p}=\frac{1}{\varepsilon}\right)$. Thus, the term $\sum_{s=t}^{\infty} \beta_{s}^{t} \frac{1}{\varepsilon} p\left(Q P\left(K_{s}\right)\right) \cdot Q P\left(K_{s}\right)=\sum_{s=t}^{\infty} \beta_{s}^{t}\left(p_{s}-c_{s}\right) \cdot Q P\left(K_{s}\right)$ is the contribution to the economic value of the bank from the economic profits earned when this bank can set a price above its long-term average cost (assuming constant returns, that is, marginal cost equal to average cost). This term will be zero if the bank is a price-taker (perfectly elastic demand).

Equation (7) will be the basis for the empirical analysis of the multi-asset Spanish banks, and for the test of the hypotheses that banks accumulated organizational capital in making ITrelated assets fully productive, and that they have market power in the loan or deposit markets. Bond and Cummins (2000) expressed caution over the potential estimation biases in investment equations on material assets that ignore the simultaneous investment in intangibles. We now add to these concerns the potential biases of ignoring intangibles and market power. 


\section{Application to the Spanish banking industry}

\subsection{Database}

Data on Spanish commercial and savings banks, from 1984 to 2003, are collected from proprietary information provided by banks to the Banco de España (balance sheets, income statements and complementary notes) at the non-consolidated level. The banks in the sample represent 89.25\% of the total banking assets in Spain in 2003 (the remainder are credit cooperatives and branches of foreign banks). The number of banks in the sample changes over time, from 160 in 1984 to 90 in 2003, because of mergers and acquisitions; the average number of observations per bank is 13.23. The paper treats the banks that result from a merger as new entities. We obtain estimates of the investment flow and capital stock of four main types of asset: Physical $\left(K^{P h}\right)$, Information Technology $\left(K^{I T}\right)$, Advertising $\left(K^{A D}\right)$ and Financial $\left(K^{F E}\right)$. Physical capital includes buildings (mainly branches) and durable assets. ${ }^{7}$ IT capital is set equal to the sum of the assets reported in the balance sheet under the heading of information technology, plus the capitalization of annual expenditures in IT reported in the income statement. ${ }^{8}$ Financial assets is the counterpart, on the asset side of the balance sheet, of bank equity remaining after financing the assets used in production and sales [Equity-(Physical + IT + Advertising)]. Regulatory requirements for the minimum capital ratio for banks explain that this difference is positive under normal conditions. Banks in the sample also report individual data on expenditures on training workers, which is used to calculate the stock of intangible capital in the form of human capital from training $\left(K^{H K}\right)$. The stocks of each of the assets are valued at current replacement cost, as described in Appendix B.

In Spain, the banking industry has been unregulated for a long period of time. In line with previous studies [Martín-Oliver and Salas-Fumás (2008)], we assume that Spanish commercial and savings banks operate in a monopolistic competition framework with product differentiation. As banks can have market power on loan markets, deposit markets, or both, we collect individual bank data of the interest paid to deposits, $I D$, and of the gross profit margins in loans, GLP (interest on loans minus opportunity cost of loans at the interbank interest rate) for the estimation of the revenues in the investment equation. For loans, we use the gross margin, rather than total interest payments, in order to avoid double-counting, since interest paid in deposits is one component of the cost of loans.

The (fundamental) economic value of the bank will be set equal to the present value of the predicted future earnings, discounted at the cost of capital of the bank. We follow the approach of Abel and Blanchard (1986) and forecast the future earnings of each bank using an ARIMA econometric model. Earnings data are obtained from accounting earnings after adjustment for differences in criteria between costs and investments:

\section{Adjusted Earnings = Accounting Earnings + Advertising Expenditures + IT Expenditures + + Accounting Amortization - Estimated Economic Depreciation of material and immaterial assets at replacement cost}

7. Banks both rent and own their branches, so the replacement cost of physical assets has been calculated after having homogenized all banks as if they owned all the branches they have. We are able to do this because we know the owned and rented branches for each bank in the sample.

8. This paper does not explicitly distinguish between "hardware" and "software" when referring to IT capital and all IT assets are named immaterial assets, because of data limitations. For example, we do not know the detailed components of IT expenditures reported in the income statement of banks. 
The economic value of a bank $i$ in year $t$ is then calculated as follows,

$$
\hat{V}_{i t}=\hat{P}_{i t}^{t}+\xi_{i, t} \hat{P}_{i, t+1}^{t}+\xi_{i, t}^{2} \hat{P}_{i, t+2}^{t}+\xi_{i, t}^{3} \bar{P}_{i}^{t} \frac{1+\bar{\rho}_{i t}}{\bar{\xi}_{i t}-\bar{\rho}_{i t}}
$$

where $\hat{P}_{i, t+s}^{t}$ are the predicted adjusted earnings of bank $i$ at time $t+s$, given the information available at time $t$ using an $A R(2)$ model; $\xi_{i, t}$ is the discount factor of each bank, inversely related to the opportunity cost of capital of that bank at time $t$. The opportunity cost of capital of the bank is set equal to the risk-free interest rate plus a risk premium that takes into account the credit risk of loans plus the risk from debt leverage.

From $t+3$ onwards, the level of profit of banks is calculated applying a constant expected growth rate $\rho_{i}$ to the average of the predictions for $t, t+1$ and $t+2, \bar{P}_{i}^{t}$. It is assumed that this rate of growth of profit is equal to the profit retention rate times the long-run Return On Equity $(R O E)$. The proxy value of the long-term growth rate $\bar{\rho}_{i t}$ is obtained assuming that banks retain one half of their earnings, and further assuming that the long-term $R O E$ is equal to the average of the ROE of the last three years (with equity valued at replacement cost). The longterm discount factor $\bar{\xi}_{i t}$ has been approximated to the average of the opportunity cost of capital of the bank in the previous three-year period. ${ }^{9}$

One debatable issue is whether our estimated economic value of the banks is more or less appropriate in valuing intangible assets as the value obtained from share prices, if the latter were available. It could be argued that our estimated economic value has some advantages over the stock market valuation, since the calculation simply follows the definition of the fundamental value of a bank according to the objective function of the model. Market analysts and investors will have no more information on economic profits and cash flows tan do we (notice that some data are not publicly reported; for example, expenditures on IT and advertising, owned versus rented branches), and so their projections to determine the recommended share price cannot be expected to be more accurate than ours. Moreover, share prices can be affected by bubbles that distort the measurement of intangibles [Bond and Cummins (2000)] and may value rents to current shareholders that cannot be attributed to intangible assets (for example, share prices may incorporate a take-over premium).

Summary statistics for the variables used in the empirical analysis are presented in Table 1 (economic value, stock of assets at replacement cost, and investment rates) and Table 2 (statistics for the variables of the empirical investment equation). Banks differ in size and in asset composition. The differences in investment rates across assets reflect differences in depreciation rates and cross-substitution among assets. The average investment rate in physical capital is around $3 \%$, similar to the depreciation rate. On the other hand, the average IT investment rate is $42 \%, 7 \mathrm{pp}$ higher than the depreciation rate. The stock of human capital at cost, from training expenditures, grows at an average rate close to $30 \%$, while the assumed depreciation rate is $20 \%$. Economic value of banks increases over time, as well as the stock of all invested assets. IT

9. In order to test for possible biases in our measure of the economic value of banks, for those banks listed on the market, we estimate the actual market value of the bank as the product of share price and number of issued shares at the end of each year (from 1987 to 2003). We then postulate and estimate a linear equation model, where the dependent variable is the actual market price, Market, and the explanatory variable is our estimated economic value of the bank, Econvalue. The results of the estimation are Market $=-79.83+1.09 \cdot$ Econvaluc (204 observations). The null hypothesis of intercept equal to zero and slope equal to one are not rejected at the $5 \%$ level of significance. Therefore, we have no evidence that our estimate of the economic value of banks is a biased estimate of their market value if they were, in fact, listed on the stock market. 
and advertising capital at constant prices increase during all the sample years, while physical capital per worker increases only until 1996 and then begins a negative trend that persists until 2003. In 2003, the estimated stock of IT capital per worker at constant prices is 6.3 times what it was in 1984, while Physical capital per worker in 2003 is 1.5 times what it was in 1984.

Figure 1 shows the time evolution of descriptive statistics for the $q$ ratio, calculated as the ratio between discounted adjusted cash flows and the assets of banks at replacement costs. The median $q$ ratio of the banks in the sample is close to 3 in 1984 and falls to 0.94 in 1994. Since then, it rises again, but remains at values lower than 2. Increasing competition in the latter part of the period (coinciding with the full liberalization of the banking sector, and with Spain joining the Euro zone) squeezed economic profits. The coefficient of variation (standard deviation divided by mean) also decrease over time, indicating convergence in the estimated $q$ across banks. For comparative purposes, Figure 1 also shows the median of the $q$ ratio calculated with raw accounting data (profits and book-reported assets). The median of the accounting-based $q$ ratio always overestimates the median of the $q$ ratio with adjusted cash flows and assets at replacement cost.

\subsection{Empirical investment equation}

The empirical formulation of the investment equation (7) is written as follows:

$$
\begin{gathered}
\frac{I_{i t}^{P h}}{K_{i t-1}^{P h}}=\varphi_{0}+\varphi_{1} \ln q_{i t}^{P h}+\sum_{j \in J}\left(\varsigma_{j} \frac{p_{j} I_{i t}^{j}}{p_{P h} K_{i t-1}^{P h}}\right)+\chi_{1} \frac{p_{H} K_{i t}^{H K}}{p_{P h} K_{i t-1}^{P h}}+\chi_{2} \frac{I_{i t}^{H K}}{K_{i t-1}^{H K}} \cdot \frac{p_{I T} I_{i t}^{I T}}{p_{P h} K_{i t-1}^{P h}}+ \\
+\gamma_{1} \frac{I D_{i t}}{p_{P h} K_{i t-1}^{P h}}+\gamma_{2} \frac{G L P}{p_{P h} K_{i t-1}^{P h}}+\eta_{i}+u_{i t} \\
J=\{I T, A d, F E\} ; \quad \eta_{i}, u_{i t} \sim i i d\left(0, \sigma_{\kappa}\right) ; \kappa=\{\eta, u\}
\end{gathered}
$$

The dependent variable is the investment rate of the Physical assets. The partial $q$ ratio of economic value over physical assets of the bank is expressed in logs; ${ }^{10}$ the coefficient

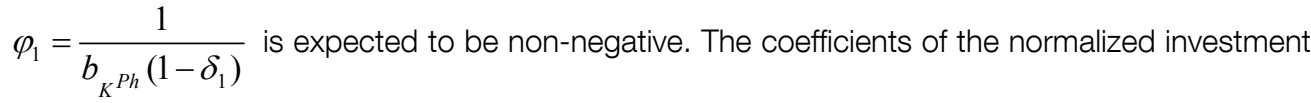
flow of the remaining assets, $\zeta$, are expected to be non-positive $\left(-\zeta_{j}=\frac{b_{K_{j}}\left(1-\delta_{K_{j}}\right)}{b_{K^{P h}}\left(1-\delta_{K^{P h}}\right)}\right.$, from(7) . We use the estimated stock of human capital from training expenditures, $p_{H K} K^{H K}$ as a proxy for the stock of intangible assets $M_{K^{I T}}$ that result from IT investment; therefore we expect $\chi_{1}=$

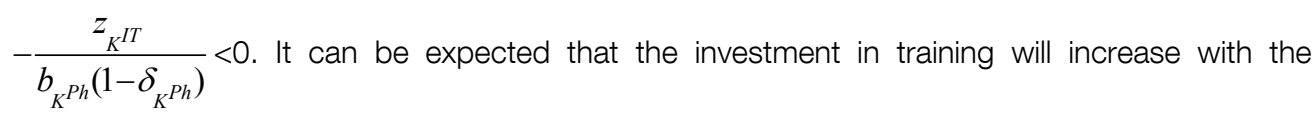
marginal return from the intangible human capital and, thus, the investment rate in training expenditures $\frac{\left(1-\delta_{H K}\right) I^{H K}}{K^{H K}}$ is taken as an approximation for $z_{K^{I T}} f^{\prime} C_{I T}$. Therefore, from (7) we also expect $\chi_{2}>0$. This implies that the combined contribution of investment in IT to the investment rate in physical capital is given by $\zeta_{I T}+\chi_{2} \frac{I^{H K}}{K^{H K}}$, decreasing with the investment rate.

10. Bond and Cummins (2001) provide an econometric justification for the semi-log approximation to the $q$ model of investment, based on a possible multiplicative structure of the measurement error in the variables. 
Finally, $\gamma_{1}<0$ and $\gamma_{2}<0$ if banks have market power in loan and deposit markets. We assume that the current (year $t$ ) interests on deposits, $I D$, and the gross margins from loans, $G L P$, are strongly correlated with the future values of the respective interest charges and revenues. ${ }^{11}$

As data on investment rates present a large cross-section and time-series variation, the investment equation will be estimated with the first-differenced GMM estimator; all the estimations will contain time-dummy variables. The use of first-differences is a common practice in panel data estimations of the $Q$ investment model [Hayashi and Inoue (1991); Blundell et al. (1992); and, more recently, Bond and Cummins (2001)]. The instruments used in the estimation are the lags $t-2$ and $t-3$ of the explanatory variables, since the contemporaneous values of investment flows, interest on loans and deposits, and other variables, could be correlated with the innovations of the disturbance term. ${ }^{12}$ The Sargan test of over-identifying restrictions and the second-order autocorrelation test will be used to assess the validity of instruments and the overall estimation: the non-rejection of the Sargan test is consistent with the compatibility of the instruments that make up the instrument matrix. The non-rejection of the hypothesis of absence of second-order autocorrelation is compatible with the use of lags of the explanatory variables of second order or more as instruments. ${ }^{13}$

\subsection{Results}

Table 3 presents the results of estimating different versions of the investment equation that, in turn, respond to alternative hypotheses about the model.

The model of Column 1 assumes that the physical assets (those reported in the balance sheet) are the only capital input of banks, and it ignores market power. The explanatory variable In $q^{P h}$ (average $q$ for physical assets in logs) has a positive and statistically significant estimated coefficient, as conventional $q$ models of investment predict. Taking into account the relationship between the parameters of both the empirical and the theoretical investment equations, the estimated value of 0.023 implies a parameter of the adjustment cost function equal to $b_{K^{P h}}=\frac{1}{\varphi\left(1-\delta_{1}\right)}=44.8$.

Column 2 of Table 3 shows the results of the estimation of the basic investment model for the multi-asset firm [equation (8)] as if there was no market power. The estimated coefficient of $\ln q^{P h}$ is also positive and statistically significant. The estimated coefficients of investment flows in IT and advertising, and of the stock of human capital from training, are negative and statistically significant. Finally, the coefficient for the investment rate in financial assets is not statistically significant. Thus, the empirical evidence indicates (consistent with the theory) that

\footnotetext{
11. Suppose a growth rate on sales of zero and a constant discount rate $\beta<1$. The predicted value for the coefficient of the revenues in the investment equation would be $\gamma_{1}=\frac{\beta}{(1-\beta) \varepsilon}$ where $\varepsilon$ is the price elasticity of demand.

12. Blundell et al. (1992) contains a thorough analysis of the proper number of lags to be used as suitable instruments in the $q$ investment equation. On the other hand, Bond and Cummins (2001) discuss the potential econometric problems in models where the explanatory variable has persistent measurement errors, as can be the case with the Tobin's $q$ calculated from stock market valuations, when these market valuations deviate from the firm's fundamental value. Our estimates of the Tobin's $q$ are obtained with earnings forecasts and estimates of fundamental values, so it is possible to identify the parameters of the model with a suitable set of instruments [Bond and Cummins (2001)].

13. The second lag would be the minimum lag that can be used as a valid instrument in the case where the explanatory variables are contemporaneously correlated with the disturbance term, and the equation is first-differenced to eliminate firmspecific effects, provided that there is no serial correlation in the first-differenced residuals $\Delta u_{i t .}$. Although the measurement errors of the $q$ used in this paper are not related to persistent deviations between stock market valuations and the firm's fundamental value (see previous footnote), for robustness purposes we have estimated the model with the instruments $q_{t-3}$ and $q_{t-4}$ instead of $q_{t-2}$ and $q_{t-3}$, to control for potential measurement errors [Blundell et al. (1992)]. The results are similar for each set of instruments.
} 
banks face positive adjustment costs when they expand the stock of material, IT, and advertising capital. However, the hypothesis that adjustment costs for financial assets are equal to zero cannot be rejected, which suggests that Spanish banks were able to respond smoothly to the requirements of regulatory capital during the sample period. The estimated coefficient of $\ln q^{P h}$ is now 0.033 , higher than the 0.023 in Column 1, and the new estimate of the adjustment cost parameter is $b_{K}{ }^{P h}=31.2 .{ }^{14}$ The differences are explained by the bias induced in the estimation of adjustment costs for material assets, when the investment rates in non-material assets are omitted from the model [Bond and Cummins (2000)]. The results indicate that, in our data sample, not controlling for the contribution to average $q$ of other productive assets (such as IT and advertising capital) overestimates the adjustment cost of investment in physical capital by $43.5 \%$.

Column 3 of Table 3 shows the estimation of the investment equation of the multi-asset banks, including the interest flows of deposits and loans, which enter into the investment model when banks have market power. The negative and statistically significant estimated coefficients of these variables are consistent with the hypothesis that banks have market power in deposit and loan markets. The estimated coefficients for the remaining explanatory variables are statistically significant and with the expected sign, except for the investment in advertising capital that now is not statistically significant. The downward differences in the estimated coefficients in Column 3, compared with those in Column 2, can be interpreted as evidence of the biases in the estimated adjustment cost parameter from excluding the variables that control for the market power of banks in the investment equation. The biases are expected to be larger for those coefficients attached to the assets of banks that sustain market power. Therefore, according to the evidence, advertising capital appears to be the asset that contributes the most to the market power of banks.

Column 4 of Table 3 shows the estimates of the investment equation for the case where the adjustment costs from the investment in IT produces valuable intangible assets. The prediction from the theoretical model is that the adjustment costs from the investment in IT capital should be a decreasing function of the marginal contribution of the built-in intangibles to the economic rents. The estimation implies a coefficient for the IT investment variable equal to $0.403-0.401 \cdot 1 / K / K^{H K}$, which is smaller for higher investment rates of human capital, as expected. For a bank that is in the $25^{\text {th }}$ percentile of the distribution of the investment rate of human capital $\left(I^{H K} / K^{H K}=0.10\right.$ from Table 1), the estimated coefficient of the investment in IT would be

14. These estimates are in line with those obtained in previous work. For instance, Hayashi and Inoue (1991) obtain estimates of the coefficient of the $\mathrm{q}$ ratio in the investment equation between 0.017 and 0.029 , with data from Japanese industrial firms in 1984-1986. Blundell et al. (1992) obtain an estimate of 0.0097 for 532 UK manufacturing companies for the 1975-1986 period, and Erickson and Whited (2000) find a coefficient between 0.033 and 0.045 for firms in Compustat during the 1992-95 period. All these papers use Tobin's q calculated with stock market values of firms. Bond and Cummins (2001) obtain a coefficient of 0.11 when the $q$ ratio is obtained from fundamental values based on analysts' earnings forecasts, and a coefficient ten times lower with the q calculated with stock market values. Our estimates of the fundamental value of banks are obtained in a similar way to those of Bond and Cummins, but our estimate of the coefficient is lower, 0.033. The economic significance of these results can be calibrated from the estimated values of the implicit adjustment costs. For example, from our own results, a one standard deviation of the investment rate in physical capital (equal to 0.079 , Table 1) from its stationary value implies an adjustment cost of $9.7 \%$ per Euro invested in the stock of physical capital (from (2), we have $C=\frac{31.2}{2} \cdot 0.079^{2} \cdot p_{P h} K^{P h}=0.097 p_{P h} K^{P h}$ ). This unrealistically high adjustment cost

estimate can be explained by the high estimated value of the adjustment cost parameter, 31.2 , and by the comparatively high standard deviation of the variable investment rate in physical capital. From Table 1, if the coefficient of variation of the investment rate in physical capital was in line with the coefficient of variation of the investment rate in the other assets, the standard deviation of the variable would have a value close to the mean. Calculating the adjustment cost for a standard deviation equal to the mean of the variable (0.0308), the cost estimate is $1.5 \%$ of the stock of physical capital, a more reasonable figure. The high dispersion and the skewness of the dependent variable may cause some concerns about the possibility that the empirical results are driven by extreme values of the dependent variable, but the results shown in Table 1 appear robust to tests performed with the data. 
$0.403-0.401 \cdot 0.10=0.36$. For a bank in the $75^{\text {th }}$ percentile $\left(I^{H K} / K^{H K}=0.55\right)$, the estimated coefficient for the IT variable is 0.18 . According to (6), and for a given marginal $q$, this reduction of the effective adjustment cost implies that the rate of investment in IT capital for the bank in the $25^{\text {th }}$ percentile will be one half of the rate for the bank in the $75^{\text {th }}$ percentile.

The last column of Table 3 shows the parameters estimated for the full model. All the previous conclusions are corroborated: intangible assets are valuable and banks have market power in both the deposit and loan markets. Also, the estimated adjustment costs parameter for the investment in financial assets is close to zero, and the estimated parameter for the investment in advertising variable is positive but not statistically significant. To verify the consistency of the results, notice that the estimated coefficient for the investment in IT variable, evaluated at the mean value of the investment rate in human capital, ${ }^{H K} / K^{H K}=0.292$ (see Table 1), is equal to $0.452-0.437 \cdot 0.292=0.324$, practically the same value as the estimate in Column 3.

\subsubsection{Recovering the parameters of the model and valuation}

This Subsection recovers the main parameters of the original investment model (parameters $b_{j}$ of the adjustment cost function), and the main variables that determine the economic value of the representative bank (marginal adjustment cost and marginal contribution from rents resulting from market power). The summary of the results is shown in Table 4. The calculations use the estimates from the last column of Table 3 and take into account the correspondence between the parameters of the empirical model in (8), and the parameters of the theoretical formulation of the investment equation (7). Financial assets and advertising capital are excluded from Table 4, since their estimated adjustment cost parameters are not statistically significant.

The estimated adjustment cost parameter for physical capital is 33.3, but the estimated marginal adjustment cost of physical capital for the representative bank is zero since the average investment rate in these assets is very close to the depreciation rate. For a bank with zero training expenditure, we estimate that the costs of intangibles built around the investment in IT capital amount to 5 Euros. This implies that the representative bank spends 5 additional Euros per Euro invested in IT capital in complementary assets in order to make this IT capital fully productive. At the same time, the results indicate that the marginal contribution to economic value of one additional Euro of stock of human capital is 40 Euros. Finally, the marginal contribution of rents from market power is 0.95 for the sample median value of the distribution of interest payments of deposits over the stock of physical assets ( 0.16 in the case of gross margin from loans).

The economic value of the representative bank is made up of the current purchase cost of market-supplied assets, the adjustment costs from making these assets productive, and the rents from market power. From Table 1, the median values of current purchase cost of physical, IT, advertising, and financial assets, amount to a total of $112.65(49.16+3.97+1.37+58.15) .{ }^{15}$ The intangibles from adjustment costs that aim to make the IT capital fully productive can be calculated as costs or as contribution to value. In the first case, the estimated cost of intangibles would be 5 times the median value of the stock of IT capital, equal to 3.97 from Table 1 . Therefore, the estimated cost of intangibles is around 20 millions of Euros. If we make the calculation in terms of the contribution of intangibles to the economic value of the bank, then this value will be equal to 40 times the median value of the stock of human capital from training $(0.47$ from Table1), which represents a total contribution also close to 20 millions. Finally, the

15. The stocks of assets are in millions of Euros at constant prices of 1983. 
contribution to market value of rents from market power are equal to the marginal contribution times the median of the stock of physical capital (equal to 49.16 from Table 1). That is, a contribution of $0.95 \cdot 49.16=46.7$ for deposits, and of $0.16 \cdot 49.16=7.8$ for loans, or a total contribution of 54.5. With all these calculations, the estimated total economic value of this representative bank would be $112.65+20+54.5=187.15$, slightly above the median economic value, from the sample data, of 181.6 (Table 1). 


\section{Conclusions and implications}

Spanish banks invested heavily in IT during the period 1984 to 2003. On average, the stock of IT capital per worker increased in this period from 2.9 to 21.1 thousands of constant Euros. This paper provides evidence of the high investment in intangible assets that was carried out at the same time as the investment in IT. According to our estimates, the average bank in the sample has spent five additional Euros in intangible assets per Euro paid in market-purchased computers and related assets. This implies that the replacement cost of the built-in intangibles represents over $10 \%$ of the economic value of the bank, and around $40 \%$ of the replacement cost of physical assets for the median values of the variables in the sample data. Expenditures in training workers are part of these adjustment costs and the resulting human capital is part of the intangible assets of the firm, though there will be other intangibles that are invisible to us. The median replacement cost of the human capital from training is around $2.5 \%(0.47 / 20)$ of the estimated replacement cost of intangibles from IT. Brynjolfsson, Hitt and Yang (2002) estimate that, in their sample of non-financial firms, each dollar invested in IT required 12 additional dollars of expenditure in intangibles. Compared to their findings, our sample of Spanish banks built a lower stock of organization capital, though the estimation procedure is also different, and comparisons of actual figures must be made with caution. We find no evidence of contribution to the economic value of banks from adjustment costs attributed to investment in physical, advertising, and financial assets. The finding that banks adjust the stock of financial assets (equity minus material and immaterial assets at replacement cost) at no appreciable adjustment cost suggests that banks did not face restrictions in meeting their economic capital requirements under changing economic conditions.

We also find that rents from market power contribute to the economic value of the representative bank: for the median values of the assets at replacement costs, the rents from market power amount to around $28 \%$ of the economic value of the bank. The empirical evidence suggests that advertising capital and, to a minor extent, physical capital and intangibles, can explain part of the market power of banks. The rest would result from attributes specific to each bank not captured by the explanatory variables of the model. Neither IT-related assets, nor financial capital, appear to be determinants of banks' economic rents. As a consequence, our empirical evidence supports the view that investment in IT does not necessarily lead to a competitive advantage for the bank.

This paper has several implications for research on the economic valuation of firms. Assuming efficient capital markets, the market value of a listed firm is equal to the present value of the expected future cash flows, discounted at the proper risk-adjusted discount factor (fundamental value). The theory presented in this paper indicates that, if the assets invested by the firm satisfy the value-maximization conditions, then the market value is expected to be equal to the sum of the replacement cost of all the productive assets, plus the rents from market power. The productive assets include material, immaterial, and intangibles, according to the definitions for each class of assets used in this paper. If the rents from market power are zero, and the replacement costs of the stock of material and immaterial assets are properly estimated, the replacement cost of intangibles can be estimated by the difference between the market value and the replacement costs of material and immaterial assets. However, if the firm has market power (positive economic rents), this difference cannot be assimilated to the contribution of intangibles to economic value (replacement costs plus attributed economic rents), since all banks' economic rents do not necessarily originate from intangible assets. 
The investment equation of the multi-asset firm is directly related to the economic value of the bank under rational, value-maximizing behaviour. The estimated adjustment costs from this equation, if any, will be part of the economic value of the firm in addition to the market purchase cost of the respective asset. The adjustment costs can then give an estimate of the replacement cost of the built-in intangibles (if any), as we show in this paper. The lesson to be drawn from our research is that one has to be careful of possible errors due to double-counting. For example, expenses for training workers on how to use computers are part of the adjustment costs attributed to investment in IT. If we calculate the cost of intangibles from the marginal adjustment cost of investment in IT, as the model suggests, we do not need to add the direct cost of intangibles, even if we could estimate them. In our analysis, the estimated stock of human capital from training at replacement cost ( 0.47 for the median bank) should not be included in the calculation of the replacement cost of all the productive assets, since it is already included in the estimated replacement cost of all the intangibles associated with investments in IT. What our calculations indicate is that the cost of human capital from training workers is only a minor part of all the costs incurred in making the IT assets fully productive, but the actual nature of the remaining intangibles is unknown to us at this point in our research.

Future research on the economic valuation and investment behaviour of the Spanish banks would benefit of a more disaggregated database on IT capital, and more precise estimates of the quality-adjusted price index of the IT capital. It would also be of interest to compare the results obtained in this paper with those obtained with stock market valuations of the equity of the banks. The number of listed banks in Spain is reduced and therefore it will be difficult to replicate our analysis only with banks from this country, but the number of banks could be expanded with listed banks from other countries. 


\section{REFERENCES}

ABEL, A. B., and O. BLANCHARD (1986). "The present value of profits and cyclical movements in investment", Econometrica, 54, 2, pp. 249-273.

BASU, S., J. FERNAL, N. OULTON and S. SIRINIVASAN (2003). The case of missing productivity growth, or does IT explain why productivity accelerated in the US but not in the UK?, NBER Macro Annual, also available as HIER Discussion Paper 2921.

BHARADWAJ, S., S. G. BHARADWAJ and B. R. KONSYNSKI (1999). "Information technology effects on firm performance as measured by Tobin's q", Management Science, 45, 7, pp. 1008-1024.

BECALLI, E. (2007). "Does IT investment improve bank performance? Evidence from Europe?", Journal of Banking and Finance, 31, 7, pp. 2205-2230.

BLAIR, M., and S. WALLMAN (2001). Unseen Wealth: Report of the Brookings Task Force on Intangibles, Brookings Institution Press, Washington DC.

BLUNDELL, R., S. BOND, M. DEVEREUX and F. SCHIANTARELLI (1992). "Investment and Tobin's q: Evidence from company panel data", Journal of Econometrics, 51, pp. 233-258.

BOND, S., and J. CUMMINS (2000). "The stock market and investment in the new economy: Some tangible facts and intangible fictions", Brookings Papers, pp. 61-124.

— (2001). Noisy share prices and the Q model of Investment, IFS, Working Paper 01/22.

BOND, S., and C. MEGHIR (1994). "Dynamic investment models and the firm's financial policy", Review of Economic Studies, 61, pp. 197-222.

BRESNAHAN, T., E. BRYNJOLFSSON and L. HITT (2002). "Information technology, workplace organization and the demand for skilled labor: Firm level evidence", Quarterly Journal of Economics, 117, pp. 339-376.

BRYNJOLFSSON, E., L. HITT and S. YANG (2002). "Intangible assets: Computers and organization capital", Brookings Papers on Economic Activity, pp. 137-181.

BRYNJOLFSSON, E., and S. YANG (1999). "The intangible costs and benefits of computer investment: Evidence from financial markets", Atlanta, Georgia: Proceedings of the International Conference on Information Systems.

BUIGES, P., A. JACQUEMIN and J. F. MARCHIPONT (eds.) (2000). Competitiveness and the Value of Intangible Assets, Edward Elgar, Mass.

CARR, N. (2003). "IT Doesn't Matter", Harvard Business Review, 81, pp. 41-50.

COCKBURN, I., and Z. GRILICHES (1988). "Industry Effects and Appropriability Measures in the Stock Market's Valuation of R\&D and Patents", American Economic Review, 78, pp. 419-23.

CORRADO, C., J. HALTIWANGER and D. SICHEL (eds.) (2005). Measuring Capital in the New Economy, NBER Studies in Income and Wealth, The University of Chicago Press: Chicago.

CORRADO C., C. HULTEN and D. SICHEL (2009). "Intangible Capital and Economic Growth", Review of Income and Wealth, 55, pp. 661-685.

CUMMINS, J. (2004). A new approach to the valuation of intangible capital, NBER Working Papers, No. 9924.

ERICKSON, T., and T. WHITED (2000). "Measurement Error and the Relationship between Investment and q", Journal of Political Economy, 108, pp. 1027-1057.

FUKAO, K., T. MIYAGAWA, K. MUKAI and Y. SHINODA (2009). "Intangible Investment in Japan: Measurement and Contribution to Economic Growth", Review of Income and Wealth, 55, pp. 717-736.

GRILICHES, Z. (1981). "Market value, R\&D and patents, Economic Letters, 7, pp. 183-187.

HALL, B. (1993). "The Stock market valuation of R\&D investment during the 1980s", American Economic Review, 83, pp. 259-264.

HALL, R. (2001). "The stock market and capital accumulation”, American Economic Review, 91, 6, pp. 1185-1202.

HAYASHI, F. (1982). "Tobin's marginal q and average q: A neoclassical interpretation”, Econometrica, 50, pp. 213-224.

HAYASHI, F., and T. INOUE (1991). "The relation between firm growth and Q with multiple capital goods: Theory and evidence from panel data on Japanese firms", Econometrica, Vol. 59, 3, pp. 731-753.

HIRSCHEY, M., and J. WEYGANDT (1985). "Amortization policy for advertising and research and development expenditures", Journal of Accounting Research, Vol. 23, pp. 326-335.

HULTEN, CH., and X. HAO (2008). What is a company really worth? Intangible capital and the "market to book" value puzzle, NBER Working Papers, No. 14548.

LEV, B. (2001). Intangibles: Management, measurement, and reporting, Brookings Institution Press, Washington, DC.

LEV, B., and S. RADHAKRISHNAN (2005). "The measurement of firm specific organizational capital", in C. Corrado, J. Haltiwanger and D. Sichel (eds.), Measuring capital in the new economy, Studies in Income and Wealth, Vol. 65, The University of Chicago Press, Chicago, pp. 73-99.

LICHTENBERG, F. (1995). "The output contribution of computer equipment and personnel: a firm level analysis", Journal of Economics of Innovation and New Technology, 3, pp. 201-217.

MARRANO, M. G., J. HASKEL and G. WALLIS (2009). "What happened to the knowledge economy? ICT, Intangible Investment, and Britain's Productivity", Review of Income and Wealth, 55, pp. 686-716.

MARTÍN-OLIVER, A., and V. SALAS-FUMÁS (2008). "The Output and Profit Contribution of Information Technology and Advertising Investments in Banks", Journal of Financial Intermediation, Vol. 17, pp. 229-255.

MARTÍN-OLIVER, A., V. SALAS-FUMÁS and J. SAURINA (2007). Measurement of Capital Stock and Input Services of Spanish Banks", Working Paper No. 0711, Banco de España. 
MAS, M., and J. QUESADA (2005). Las nuevas tecnologías y el crecimiento económico en España, Fundación BBVA, Madrid.

OLINER, S., D. SICHEL and K. STIROH (2007). "Explaining a Productive Decade", Brookings Papers on Economic Activity, 1, pp. 81-152.

PRESCOTT, E., and M. VISSCHER (1980). "Organization capital”, Journal of Political Economy, 88, 3, pp. 446-461.

SCHIANTARELLY, F., and D. GEORGOUTSOS (1990). "Imperfect competition, Tobin's q and investment: Evidence from aggregate UK data", European Economic Review, 34, pp. 1061-1078.

VILLALONGA, B. (2004). "Intangible resources, Tobin's q and sustainability of performance differences", Journal of Economic Behaviour and Organization, 54, pp. 205-230.

WILDASIN, D. (1984). "The q Theory of Investment with Many Capital Goods", The American Economic Review, 74, pp. 203210. 
Table 1: Descriptive statistics of market value, capital stocks and Investment rates, 1984-2003

\begin{tabular}{|c|c|c|c|c|c|}
\hline & Average & Median & Std.Dev. & P25 & P75 \\
\hline Market value $V_{\text {it }}(\mathrm{m} €)$ & 799.6 & 181.6 & 2,423 & 58.11 & 565.4 \\
\hline \multicolumn{6}{|l|}{ Capital stocks (m€) } \\
\hline$K^{P h}$ & 166.5 & 49.16 & 427.3 & 14.40 & 128.8 \\
\hline$K^{\prime T}$ & 7.38 & 3.97 & 8.04 & 1.03 & 10.85 \\
\hline$K^{A D}$ & 3.46 & 1.37 & 4.19 & 0.32 & 5.39 \\
\hline$K^{F E}$ & 208.5 & 58.15 & 411.1 & 18.18 & 201.2 \\
\hline$K^{H K}$ & 2.3 & 0.47 & 6.4 & 0.00 & 4.8 \\
\hline \multicolumn{6}{|l|}{ Investment rates (\%) } \\
\hline$\rho^{P h} / K^{P h}$ & 3.08 & 1.70 & 7.92 & 0.47 & 5.47 \\
\hline$I^{I T} / K^{I T}$ & 41.99 & 41.64 & 14.53 & 34.10 & 49.41 \\
\hline$A D / K^{A D}$ & 37.30 & 36.05 & 13.03 & 31.19 & 42.06 \\
\hline IFE / $K^{F E}$ & 17.00 & 13.15 & 35.66 & 4.97 & 27.22 \\
\hline$I^{H K} / K^{H K}$ & 29.21 & 25.29 & 18.43 & 10.13 & 55.60 \\
\hline
\end{tabular}


Table 2: Descriptive statistics of the dependent and explanatory variables

\begin{tabular}{|c|c|c|c|c|c|}
\hline & Average & Median & Std.Dev. & P25 & P75 \\
\hline \multicolumn{6}{|c|}{ Dependent variable } \\
\hline$\rho^{P h} / K^{P h}$ & 3.08 & 1.70 & 7.92 & 0.47 & 5.47 \\
\hline \multicolumn{6}{|c|}{ Explanatory variables } \\
\hline$q^{P h}$ & 5.7 & 4.07 & 6.1 & 1.23 & 8.3 \\
\hline$I^{T} / K^{P h},(\%)$ & 7.7 & 6.0 & 7 & 3.41 & 9.7 \\
\hline${ }^{A d} / K^{P h},(\%)$ & 2.6 & 2.07 & 2.1 & 0.94 & 3.6 \\
\hline$I^{F E} / K^{P h},(\%)$ & 25.35 & 12.79 & 79.29 & 0.97 & 28.11 \\
\hline$K^{H K} / K^{P h},(\%)$ & 0.95 & 0.57 & 1.45 & 0.06 & 1.38 \\
\hline$I D / K^{P h},(\%)$ & 114.6 & 95.17 & 115.9 & 50.53 & 148.9 \\
\hline$G L P / K^{P h},(\%)$ & 26.9 & 18.53 & 44.5 & 1.29 & 37.5 \\
\hline
\end{tabular}


Table 3: Estimations of the investment equation

\begin{tabular}{|c|c|c|c|c|c|c|c|c|}
\hline$q^{P h}$ & $\begin{array}{l}0.023 \quad \text { *** } \\
(0.008)\end{array}$ & $\begin{array}{r}0.033 \\
(0.007)\end{array}$ & 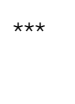 & $\begin{array}{r}0.031 \\
(0.010)\end{array}$ & 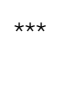 & $\begin{array}{r}0.034 \\
(0.007)\end{array}$ & $* * \star$ & $\begin{array}{r}0,031 \\
(0.010)\end{array}$ \\
\hline$I^{T} / K^{P h}$ & & $\begin{array}{l}-0.301 \\
(0.110)\end{array}$ & 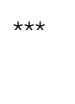 & $\begin{array}{l}-0.325 \\
(0.132)\end{array}$ & ** & $\begin{array}{l}-0.403 \\
(0.141)\end{array}$ & 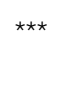 & $\begin{array}{l}-0.452 \\
(0.164)\end{array}$ \\
\hline $\mathrm{Ad} / K^{P h}$ & & $\begin{array}{l}-1.428 \\
(0.580)\end{array}$ & ** & $\begin{array}{l}-1.405 \\
(0.908)\end{array}$ & & $\begin{array}{l}-1.176 \\
(0.545)\end{array}$ & ** & $\begin{array}{l}-0.763 \\
(0.862)\end{array}$ \\
\hline IFE $/ K^{P h}$ & & $\begin{array}{l}-0.003 \\
(0.005)\end{array}$ & & $\begin{array}{l}-0.010 \\
(0.010)\end{array}$ & & $\begin{array}{l}-0.002 \\
(0.005)\end{array}$ & & $\begin{array}{l}-0, .006 \\
(0.009)\end{array}$ \\
\hline$K^{H K} / K^{P h}$ & & $\begin{array}{l}-1.655 \\
(0.496)\end{array}$ & $* \star *$ & $\begin{array}{l}-1.408 \\
(0.412)\end{array}$ & $\star \star \star ~$ & $\begin{array}{l}-1.493 \\
(0.535)\end{array}$ & 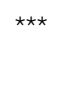 & $\begin{array}{l}-1.240 \\
(0.399)\end{array}$ \\
\hline$\mu^{I T} / K^{P h} \cdot l^{H K} / K^{H K}$ & & & & & & $\begin{array}{r}0.401 \\
(0.187)\end{array}$ & ** & $\begin{array}{r}0.437 \\
(0.185)\end{array}$ \\
\hline$I D / K^{P h}$ & & & & $\begin{array}{l}-0.027 \\
(0.015)\end{array}$ & * & & & $\begin{array}{l}-0.031 \\
(0.016)\end{array}$ \\
\hline$G L P / K^{P h}$ & & & & $\begin{array}{l}-0.025 \\
(0.015)\end{array}$ & * & & & $\begin{array}{l}-0.027 \\
(0.016)\end{array}$ \\
\hline $\begin{array}{r}\text { Time } \\
\text { Dummies }\end{array}$ & Yes & Yes & & Yes & & Yes & & Yes \\
\hline Sargan & 0.115 & 0.089 & & 0.101 & & 0.157 & & 0.171 \\
\hline $1^{\text {st }}$ order & 0.000 & 0.000 & & 0.000 & & 0.000 & & 0.000 \\
\hline $2^{\text {nd }}$ order & 0.368 & 0.697 & & 0.939 & & 0.760 & & 0.894 \\
\hline N.Obs & 1667 & 1667 & & 1667 & & 1667 & & 1667 \\
\hline
\end{tabular}

Notes:

$(")=$ Significant at 1\%; $(")=$ Significant at $5 \%()=$ Significant at 10\%. Standard errors are in parentheses.

The estimation method is First-Difference GMM.

Sargan and $1^{\text {st }}$ and $2^{\text {nd }}$ order present the $p$-values of the Sargan test and the tests of no existence of first and second-order autocorrelation, respectively. 
Table 4: Estimated parameters of the investment equation, marginal adjustment costs and marginal contributions to value, for the representative bank.

ADJUSTMENT COST PARAMETER (b)

Physical Assets

IT Assets $\left(I^{K H} / K^{K H}=0\right)$

IMPLICIT MARGINAL ADJUSTMENT COST ( $\left.C_{1}^{\prime}{ }_{1 j} / p_{\mathrm{j}}\right)$

Physical Assets

IT Assets $\left(K H / K^{K H}=0\right)$

MARGINAL RETURN

Intangibles $\left(z_{k}\right)$

$$
z_{K}=\frac{\chi_{1}}{\varphi_{1}}
$$$$
\frac{1.24}{0.031}=40
$$

$$
b_{K^{I T}}\left(1-\delta_{K^{I T}}\right) \frac{I^{I T}}{K^{I T}}-1 \quad 22.4(1-0.35) 0.42-1 \approx 5
$$

CONTRIBUTION FROM MARKET POWER

$$
\begin{array}{ll}
b_{K^{P h}}=\frac{1}{\varphi_{1}\left(1-\delta_{K^{P h}}\right)} & \frac{1}{0.031 \cdot(1-0.03)}=33.3 \\
b_{K^{I T}}=\frac{\zeta_{K^{I T}}}{\varphi_{1}\left(1-\delta_{K^{I T}}\right)} & \frac{0.452}{0.031(1-0.35)}=22.4
\end{array}
$$

Deposits

Loans
The estimated marginal adjustment cost is obtained from the approximation $\frac{\lambda_{j}}{p_{j}} \approx b_{j} \frac{\left(1-\delta_{j}\right) I_{j}}{K_{j t-1}} \approx 1+C_{I_{j t}^{\prime}}^{\prime} / p_{j}$. Investment rates and ratios of interest on deposits and interest of loans over physical assets are median values of the respective variables from Table 1 and Table 2. 
Figure 1: Time evolution of descriptive statistics of the estimated Tobin's $Q$
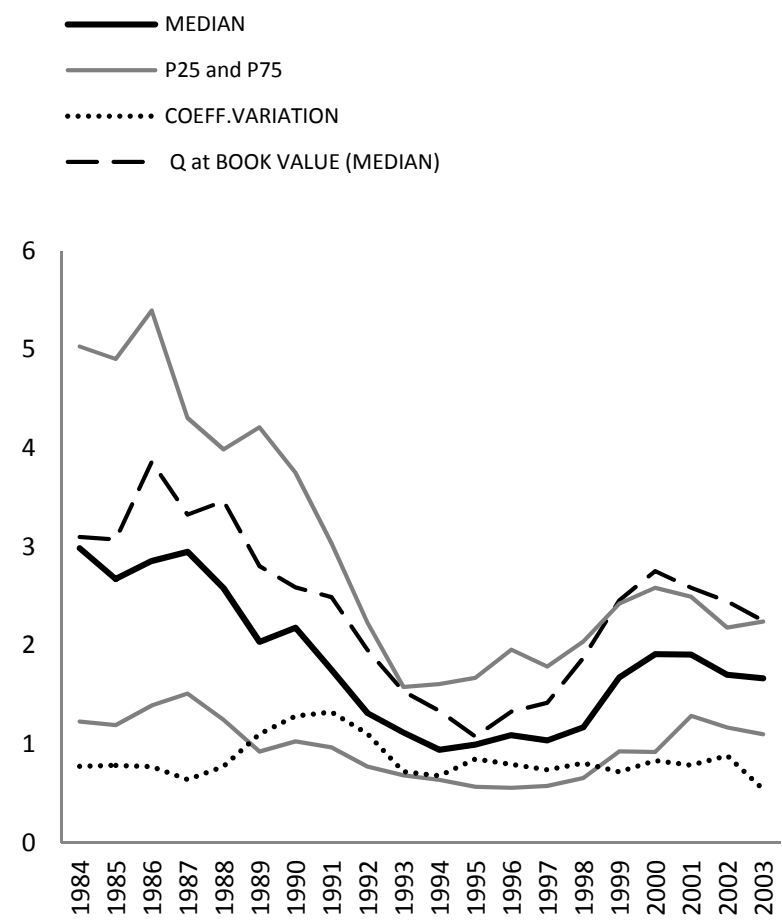


\section{Appendix A. Derivation of optimization problem of the firm}

The economic value of the firm in period $t, V_{t}$, will be equal to the present value of expected future cash flows,

$$
V_{t}=E_{t}\left\{\sum_{s=t}^{\infty} \beta_{s}^{t} \cdot \Pi\left(K_{s}, M_{s}, I_{s}, e_{s}\right)\right\}
$$

where $E_{t}$ is the expectations operator, conditional on the information available at the beginning of period $t$, and $\beta_{s}$ is the discount factor.

The optimisation problem of the firm is to choose $\boldsymbol{I}, \boldsymbol{K}$ and $\boldsymbol{M}$ such that

$$
\text { Maximize } V_{t}=E_{t}\left\{\sum_{s=t}^{\infty} \beta_{s}^{t} \cdot \Pi\left(K_{s}, M_{s}, I_{s}, e_{s}\right)\right\}
$$

subject to (A1), (A2) and (A3).

If $\lambda_{j, t+s}$ is the multiplier of the respective constraint in (A1) and $z_{j, t+s}$ the respective multiplier of (A3), the first order conditions of the maximization problem are, respectively for $I, K$ and $M$ :

$$
\begin{aligned}
& -\Pi_{I j t}^{\prime}\left(K_{t}, M_{t}, I_{t}, e_{t}\right)=p_{j t}+C_{I j t}^{\prime}-z_{j t} f_{C j t}^{\prime} C_{I j t}^{\prime}=\lambda_{j t} \\
\lambda_{j t}=\left(\frac{\partial \Pi_{t}}{\partial K_{j t}}\right)+\left(1-\delta_{j}\right) \beta_{t+1}^{t} E_{t}\left[\lambda_{j, t+1}\right] & \\
= & E_{t}\left[\sum_{s=0}^{\infty} \beta_{s}^{t}\left(\left(1-\delta_{j}\right)^{s}\left(\frac{\partial \Pi_{t+s}}{\partial K_{j, t+s}}\right)\right] \quad \forall j=1, \ldots, N\right. \\
z_{j t}= & \left(\frac{\partial \prod_{t}}{\partial M_{j t}}\right)+\left(1-x_{j}\right) \beta_{t+1}^{t} E_{t}\left[z_{j, t+1}\right] \\
= & E_{t}\left[\sum_{s=0}^{\infty} \beta_{s}^{t}\left(\left(1-z_{j}\right)^{s}\left(\frac{\partial \prod_{t+s}}{\partial M_{j, t+s}}\right)\right] \quad \forall j=1, \ldots, N\right.
\end{aligned}
$$

If price is a function of quantity, for any time period $t$ we have $\frac{\partial \Pi}{\partial J}=p(Q) \frac{\partial Q}{\partial J}+Q \frac{\partial p}{\partial Q} \frac{\partial Q}{\partial J}-\frac{\partial C}{\partial J}$ for $J=K, M$. Let $\varepsilon=-\frac{\partial Q}{\partial p} \frac{p}{Q}$ be the price elasticity of demand changed of sign (positive value). 
If $Q=F(K, M)$ is linear homogeneous in $K$ and $M$ then,

$$
\sum_{j} K_{j} \frac{\partial \Pi}{\partial K_{j}}+\sum_{j} M_{j} \frac{\partial \Pi}{\partial M_{j}}=p(Q) Q-\frac{1}{\varepsilon} p(Q) Q-\sum_{j} K_{j} \frac{\partial C}{\partial K_{j}} .
$$

Since $C$ () does not depend on $M$. Multiplying both sides of (A5) by $K_{j}$ and adding and subtracting $\lambda_{j t} I_{j t}$ we have

$$
\lambda_{j t} K_{j t}=\left(\frac{\partial \Pi_{t}}{\partial K_{j t}}\right) K_{j t}+\lambda_{j t} I_{j t}-\lambda_{j t} I_{j t}+\left(1-\delta_{j}\right) \beta_{t+1}^{t} E_{t}\left[\lambda_{j, t+1}\right] K_{j t}
$$

Making use of (A4) and arranging the terms,

$$
\lambda_{j t}\left(K_{j t}-I_{j t}\right)=\left(\frac{\partial \Pi_{t}}{\partial K_{j t}}\right) K_{j t}+\left(\frac{\partial \Pi_{t}}{\partial I_{j t}}\right) I_{j t}+\left(1-\delta_{j}\right) \beta_{t+1}^{t} E_{t}\left[\lambda_{j, t+1}\right] K_{j t}
$$

Repeating the exercise with $M_{j}$ in (A6),

$$
z_{j t} M_{j t}=\left(\frac{\partial \Pi_{t}}{\partial M_{j t}}\right) M_{j t}+\left(1-x_{j}\right) \beta_{t+1}^{t} E_{t}\left[z_{j, t+1}\right] M_{j t}
$$

Since the adjustment cost function $C_{t}(\mathrm{l})$ in (A2) is also linear homogeneous in $\mathrm{K}$ and $I$, summing over all $j$ and taking into account (A7) we have,

$$
\begin{aligned}
& \sum_{j} \lambda_{j t}\left(K_{j t}-I_{j t}\right)+\sum_{j} z_{j t} M_{j t}=\Pi_{t}-\frac{1}{\varepsilon} p_{t}(Q) Q_{t}+\sum_{j}\left(1-\delta_{j}\right) \beta_{t+1}^{t} E_{t}\left[\lambda_{j, t+1}\right] K_{j t}+ \\
& \sum_{j}\left(1-x_{j}\right) \beta_{t+1}^{t} E_{t}\left[z_{j, t+1}\right] M_{j t}
\end{aligned}
$$

Solving recursively,

$$
\sum_{j} \lambda_{j t}\left(K_{j t}-I_{j t}\right)+\sum_{j} z_{j t} M_{j t}+\sum_{s=t} \beta_{s}^{t} \frac{1}{\varepsilon} p_{t}(Q) Q_{t}=E_{t}\left(\sum_{s=0}^{\infty} \beta_{t+s}^{t} \Pi_{t+s}\right)=V_{t}
$$

Finally, the economic value at the optimal solution is equal to,

$$
V_{t}=\sum_{j}^{M} \lambda_{j t}\left(K_{j t}-I_{j t}\right)+\sum_{j} z_{j t} M_{j t}+\sum_{s=t}^{\infty} \beta_{s}^{t} \frac{1}{\varepsilon} p\left(Q\left(K_{s}\right)\right) \cdot Q\left(K_{s}\right)
$$

The investment model in the main text follows from (A8), (A4), (A5) and (A6) for the particular case where only one asset, IT, generates intangible assets as a result of adjustment costs. 


\section{Appendix B. Summary of the methodology used to estimate the stock of material and immaterial assets for Spanish banks}

For each bank, data are available on the year-by-year investment flow in Physical assets, Advertising, and IT. Data are obtained from confidential accounting statements reported by banks to the Banco de España [see Martín-Oliver, Salas-Fumás and Saurina (2007) for more details]. The stock of a particular asset in year $t$, at current replacement cost, is obtained applying the permanent inventory method:

$$
p_{t} K_{t}=p_{t} I_{t}+\frac{1-\phi}{1+\mu} \cdot \frac{p_{t}}{p_{t-1}} \cdot\left(p_{t-1} \cdot K_{t-1}\right)
$$

where $I_{t}$ is the gross investment flow of new capital services in year $t ; K_{t}$ the stock of homogeneous capital services at the end of year $t ; \phi$ the depreciation rate of the asset used in production activities during a one-year period; $\mu$ the rate of technological progress incorporated into capital services invested during one year, with respect to those invested one year before, and $p_{t}$ is the price of one unit of services in period $t$. The term $(1-\phi) /(1+\mu)$ will be substituted by $(1-\delta)$ where $\delta$ is the overall economic depreciation rate.

For each bank, we estimate the yearly investment flow in Physical assets, Advertising, IT, Financial assets, and Human Capital. Data come from the confidential accounting statements reported by commercial and savings banks to the Banco de España, beginning in 1980. The price indices used for the estimation of $p_{t} / p_{t-1}$ and the values of the depreciation rates, $\delta$, that enter into the permanent inventory equation, are summarized in Table B1. The depreciation rates are in line with those used in the literature: Hirschey and Weygandt (1985) for advertising, Litchenberg (1995) for IT and Hall (1993) for R\&D/ human capital. Financial assets do not depreciate. The physical assets include buildings, for which we assume a depreciation rate of $2.5 \%$, and equipment, with a depreciation rate of $15 \%$. The weighted depreciation rate for the sum of the two rates gives a composite depreciation rate of $3 \%$ used in the calculation.

A price index of quality-adjusted IT capital is not available. Mas and Quesada (2005) estimate price indices for hardware and for software assets in Spain; their estimates show a decreasing trend in the prices of quality-adjusted hardware, but an increase in the price index of quality-adjusted software. In this paper, we assume that the rate of technical progress incorporated in IT capital has a magnitude similar to the increase in production costs, resulting in $1 /(1+\mu)=p_{t} / p_{t-1}$. This is equivalent to assuming that the current values of the stock of all IT capital are at constant prices (i.e. the price index is set equal to 1). The zero inflation rate of the price of quality-adjusted IT capital services contrasts the $-15 \%$ to $-20 \%$ decline assumed in other studies with US data [Litchenberg (1995)]. The results of Mas and Quesada (2005), and our assumption of zero inflation, can be justified due to the higher general inflation in Spain than in the US, and because, in general, technological innovations are introduced later in Spain than in the US, and they sell at a starting price lower than the price at which they were first introduced in the market. 
Table B1: Sources of data in the computation of capital stocks at replacement cost.

\begin{tabular}{|c|c|c|c|}
\hline & Investment flow & $\begin{array}{l}\delta=\text { Economic } \\
\text { Depreciation }\end{array}$ & Price Index \\
\hline \multicolumn{4}{|l|}{ Material } \\
\hline Buildings & $\begin{array}{l}\text { Difference between book value at } t \\
\text { and } t-1 \text { from balance sheet data }\end{array}$ & 0.03 & $\begin{array}{c}\text { Residential (Ministerio } \\
\text { de Vivenda) }\end{array}$ \\
\hline Non-IT Equipment & Book value & 0.15 & Market Services (INE) \\
\hline \multicolumn{4}{|l|}{ Immaterial } \\
\hline IT Equipment & Book value & 0.35 & See in the text \\
\hline IT Services & $\begin{array}{c}\text { Expenditures flow from income } \\
\text { statement }\end{array}$ & 0.35 & See in the text \\
\hline Advertising & $\begin{array}{c}\text { Expenditures flow from income } \\
\text { statement }\end{array}$ & 0.35 & Market Services (INE) \\
\hline Training & $\begin{array}{c}\text { Expenditures flow from income } \\
\text { statement }\end{array}$ & 0.20 & $\begin{array}{c}\text { Educational Services } \\
\text { (INE) }\end{array}$ \\
\hline Financial Assets & $\begin{array}{l}\text { Difference between book value at } t \\
\text { and } t-1 \text { from balance sheet data }\end{array}$ & 0.00 & $\begin{array}{l}\text { Consumption Price } \\
\text { Index (INE) }\end{array}$ \\
\hline
\end{tabular}




\title{
BANCO DE ESPAÑA PUBLICATIONS
}

\author{
WORKING PAPERS
}

0901 PRAVEEN KUJAL AND JUAN RUIZ: International trade policy towards monopoly and oligopoly

0902 CATIA BATISTA, AITOR LACUESTA AND PEDRO VICENTE: Micro evidence of the brain gain hypothesis: The case of Cape Verde.

0903 MARGARITA RUBIO: Fixed and variable-rate mortgages, business cycles and monetary policy.

0904 MARIO IZQUIERDO, AITOR LACUESTA AND RAQUEL VEGAS: Assimilation of immigrants in Spain: A longitudinal analysis.

0905 ÁNGEL ESTRADA: The mark-ups in the Spanish economy: international comparison and recent evolution.

0906 RICARDO GIMENO AND JOSÉ MANUEL MARQUÉS: Extraction of financial market expectations about inflation and interest rates from a liquid market.

0907 LAURA HOSPIDO: Job changes and individual-job specific wage dynamics.

0908 M. ${ }^{a}$ DE LOS LLANOS MATEA AND JUAN S. MORA-SANGUINETTI: Developments in retail trade regulation in Spain and their macroeconomic implications. (The original Spanish version has the same number.)

0909 JAVIER MENCÍA AND ENRIQUE SENTANA: Multivariate location-scale mixtures of normals and mean-varianceskewness portfolio allocation.

0910 ALICIA GARCÍA-HERRERO, SERGIO GAVILÁ AND DANIEL SANTABÁRBARA: What explains the low profitability of Chinese banks?

0911 JAVIER MENCÍA: Assessing the risk-return trade-off in loans portfolios.

0912 MAXIMO CAMACHO AND GABRIEL PEREZ-QUIROS: Ñ-STING: España Short Term Indicator of Growth.

0913 RAQUEL VEGAS, ISABEL ARGIMÓN, MARTA BOTELLA AND CLARA I. GONZÁLEZ: Retirement behaviour and retirement incentives in Spain.

0914 FEDERICO CINGANO, MARCO LEONARDI, JULIÁN MESSINA AND GIOVANNI PICA: The effect of employment protection legislation and financial market imperfections on investment: Evidence from a firm-level panel of EU countries.

0915 JOSÉ MANUEL CAMPA AND IGNACIO HERNANDO: Cash, access to credit, and value creation in M\&As.

0916 MARGARITA RUBIO: Housing market heterogeneity in a monetary union.

0917 MAXIMO CAMACHO, GABRIEL PEREZ-QUIROS AND HUGO RODRÍGUEZ MENDIZÁBAL: High-growth Recoveries, Inventories and the Great Moderation.

0918 KAI CHRISTOFFEL, JAMES COSTAIN, GREGORY DE WALQUE, KEITH KUESTER, TOBIAS LINZERT, STEPHEN MILLARD AND OLIVIER PIERRARD: Wage, inflation and employment dynamics with labour market matching.

0919 JESÚS VÁZQUEZ, RAMÓN MARÍA-DOLORES AND JUAN-MIGUEL LONDOÑO: On the informational role of term structure in the U.S. monetary policy rule.

0920 PALOMA LÓPEZ-GARCÍA AND SERGIO PUENTE: What makes a high-growth firm? A probit analysis using Spanish firm-level data.

0921 FABIO CANOVA, MATTEO CICCARELLI AND EVA ORTEGA: Do institutional changes affect business cycles? Evidence from Europe.

0922 GALO NUÑO: Technology, convergence and business cycles.

0923 FRANCISCO DE CASTRO AND JOSÉ LUIS FERNÁNDEZ: The relationship between public and private saving in Spain: does Ricardian equivalence hold?

0924 GONZALO FERNÁNDEZ-DE-CÓRDOBA, JAVIER J. PÉREZ AND JOSÉ L. TORRES: Public and private sector wages interactions in a general equilibrium model.

0925 ÁNGEL ESTRADA AND JOSÉ MANUEL MONTERO: R\&D investment and endogenous growth: a SVAR approach.

0926 JUANA ALEDO, FERNANDO GARCÍA-MARTÍNEZ AND JUAN M. MARÍN DIAZARAQUE: Firm-specific factors influencing the selection of accounting options provided by the IFRS: Empirical evidence from Spanish market.

0927 JAVIER ANDRÉS, SAMUEL HURTADO, EVA ORTEGA AND CARLOS THOMAS: Spain in the euro: a general equilibrium analysis.

0928 MAX GILLMAN AND ANTON NAKOV: Monetary effects on nominal oil prices.

0929 JAVIER MENCÍA AND ENRIQUE SENTANA: Distributional tests in multivariate dynamic models with Normal and Student $t$ innovations.

0930 JOAN PAREDES, PABLO BURRIEL, FRANCISCO DE CASTRO, DANIEL GARROTE, ESTHER GORDO AND JAVIER J. PÉREZ: Fiscal policy shocks in the euro area and the US: an empirical assessment.

1. Previously published Working Papers are listed in the Banco de España publications catalogue. 
0931 TERESA LEAL, DIEGO J. PEDREGAL AND JAVIER J. PÉREZ: Short-term monitoring of the Spanish Government balance with mixed-frequencies models.

0932 ANTON NAKOV AND GALO NUÑO: Oilgopoly: a general equilibrium model of the oil-macroeconomy nexus.

0933 TERESA LEAL AND JAVIER J. PÉREZ: Análisis de las desviaciones presupuestarias aplicado al caso del presupuesto del Estado.

0934 JAVIER J. PÉREZ AND A. JESÚS SÁNCHEZ: Is there a signalling role for public wages? Evidence for the euro area based on macro data.

0935 JOAN PAREDES, DIEGO J. PEDREGAL AND JAVIER J. PÉREZ: A quarterly fiscal database for the euro area based on intra-annual fiscal information.

1001 JAVIER ANDRÉS, ÓSCAR ARCE AND CARLOS THOMAS: Banking competition, collateral constraints and optimal monetary policy.

1002 CRISTINA BARCELÓ AND ERNESTO VILLANUEVA: The response of household wealth to the risk of losing the job: evidence from differences in firing costs.

1003 ALEXANDER KARAIVANOV, SONIA RUANO, JESÚS SAURINA AND ROBERT TOWNSEND: No bank, one bank, several banks: does it matter for investment?

1004 GABRIEL PEREZ-QUIROS AND HUGO RODRÍGUEZ MENDIZÁBAL: Asymmetric standing facilities: an unexploited monetary policy tool.

1005 GABRIEL JIMÉNEZ, JOSE A. LOPEZ AND JESÚS SAURINA: How does competition impact bank risk-taking?

1006 GIUSEPPE BERTOLA, AURELIJUS DABUSINSKAS, MARCO HOEBERICHTS, MARIO IZQUIERDO, CLAUDIA KWAPIL, JEREMI MONTORNĖS AND DANIEL RADOWSKI: Price, wage and employment response to shocks: evidence from the WDN Survey.

1007 JAVIER MENCÍA: Testing non-linear dependence in the Hedge Fund industry.

1008 ALFREDO MARTÍN-OLIVER: From proximity to distant banking: Spanish banks in the EMU.

1009 GALO NUÑO: Optimal research and development expenditure: a general equilibrium approach.

1010 LUIS J. ÁLVAREZ AND PABLO BURRIEL: Is a Calvo price setting model consistent with micro price data?

1011 JENS HAGENDORFF, IGNACIO HERNANDO, MARÍA J. NIETO AND LARRY D. WALL: What do premiums paid for bank M\&As reflect? The case of the European Union.

1012 DAVID DE ANTONIO LIEDO: General equilibrium restrictions for dynamic factor models.

1013 JAMES COSTAIN, JUAN F. JIMENO AND CARLOS THOMAS: Employment fluctuations in a dual labor market.

1014 LUIS M. VICEIRA Y RICARDO GIMENO: The euro as a reserve currency for global investors.

1015 PALOMA LÓPEZ-GARCÍA AND JOSÉ MANUEL MONTERO: Understanding the Spanish business innovation gap: The role of spillovers and firms' absorptive capacity.

1016 AITOR LACUESTA AND SERGIO PUENTE: El efecto del ciclo económico en las entradas y salidas de inmigrantes en España.

1017 REBEKKA CHRISTOPOULOU, JUAN F. JIMENO AND ANA LAMO: Changes in the wage structure in EU countries.

1018 THOMAS BREUER, MARTIN JANDAČKA, JAVIER MENCÍA AND MARTIN SUMMER: A systematic approach to multi-period stress testing of portfolio credit risk.

1019 LUIS J. ÁLVAREZ AND PABLO BURRIEL: Micro-based estimates of heterogeneous pricing rules: The United States vs. the euro area.

1020 ALFREDO MARTÍN-OLIVER AND VICENTE SALAS-FUMÁS: I.T. investment and intangibles: Evidence from banks.

\section{BANCODEESPAÑA}

Eurosistema
Unidad de Publicaciones Alcalá, 522; 28027 Madrid

Telephone +3491338 6363. Fax +34919986488

E-mail: publicaciones@bde.es www.bde.es 